\title{
English Language Anxiety of Tertiary Level Learners in Bangladesh: Level and Sources
}

\author{
Md. Abdullah Al Mamun ${ }^{1}$ \\ ${ }^{1}$ Department of English, Jashore University of Science and Technology, Jashore, Bangladesh \\ Correspondence: Md. Abdullah Al Mamun, Department of English, Jashore University of Science and \\ Technology, Jashore, Bangladesh.
}

Received: September 15, 2021

Accepted: October 4, $2021 \quad$ Online Published: October 14, 2021

doi: $10.5539 /$ elt.v14n11p49

URL: https://doi.org/10.5539/elt.v14n11p49

\begin{abstract}
The prime objectives of this study were to unveil the level of anxiety and the sources of English language anxiety of the tertiary level students of Bangladesh. Through a questionnaire survey using Foreign Language Classroom Anxiety Scale developed by Horwitz et al. (1986), the study found that most of the tertiary level learners have high anxiety of English as a foreign language. Based on an exploratory factor analysis with principal component analysis and varimax rotation (Kaiser Normalization), a four-factor (communication anxiety, comprehension and test anxiety, fear of negative evaluation, and lack of anxiety) solution emerged. Following a close analysis of the EFA and other established valid models, the study found that six components, namely, speaking anxiety, fear of negative evaluation, peer pressure/social-image anxiety, comprehension-related anxiety, negative attitude towards class, and test anxiety were the main sources of anxiety, which need to be addressed for alleviating the anxiety of the students.
\end{abstract}

Keywords: foreign language anxiety, English language teaching, sources of anxiety, classroom anxiety

\section{Introduction}

The degree of successful acquisition of a second or foreign language is determined by social and psychological factors (Schumann, 1978). Besides the social factors like social distance, dominance, acculturation, etc., psychological factors as anxiety, personality, motivation, etc., have been studied by a huge number of researchers. Learning English as a second language (ESL) or English as a foreign language (EFL) has been found negatively affected by the learner's psychological factors like anxiety, lack of motivation, and lack of confidence etc. (Aida, 1994; Horwitz, 1986, MacIntyre \& Gardner, 1991; Salehi \& Marefat, 2014; Rashid et al., 2020). The comprehension and performance capabilities of the learners get restricted by the high level of anxiety because by creating stress or fear, anxiety consolidates the negative impacts of the affective factors, and the learners cannot benefit from the best (Anandari, 2015; Arnold, 2000; Aust, 2016 as in Rashid et al., 2020). Due to the importance of handling anxiety for academic achievement or successful acquisition of a Target Language (TL), it has got a good deal of attention.

Anxiety has been defined from several perspectives, but all of them focus on the central aspect of its being a psychological feeling of human beings (Spielberger, 1983), which is introspective and individual in nature. He associates this feeling with some other integrative psycho-motor conditions like tension, apprehension, nervousness, and worries linked with an automatic nervous system (cited in Horwitz et al., 1986, p. 125). It can be situation-specific or general. Freud has defined it as "something felt, an emotional state that includes feelings of apprehension, nervousness, and worry accompanied by psychological arousal (Weiner \& Craighead, 2010 as in Demirdaş \& Bozdoğan, 2013)."

Anxiety or fear is related to many other issues of SLA or FLA. However, most of the studies have focused on language anxiety and performance (Aida, 1994; Horwitz, 1986, 2001; MacIntyre \& Gardner, 1989; Philips, 1992, Aydin, 2009; Sultana, 2018), gender and anxiety (Marwan, 2007; Sertçetin, 2006; Öner \& Gedikoğlu, 2007), anxiety and self-efficacy (Dörnyei, 2009; Piniel, \& Csizér, 2013), anxiety and classroom participation (Das, 2020), etc. All these studies show that the performance-related anxieties like communication apprehension, test anxiety, fear of negative evaluation (Horwitz et al., 1986); speech anxiety, and fear of failing to achieve the desired linguistic competency (Aida, 1994) have to be addressed carefully for the effective materialization of learning EFL endeavors. 
Contextual factors highly affect the successful and effective learning of EFL. Anxiety, a personal psychological phenomenon, has to be addressed, keeping in mind the contextual and environmental factors and individual characteristics of the learners. Thus, it is imperative that for a particular situation, the type and level of anxiety and the variables dominating the anxiety type are found out. Therefore, it would help to build a context-sensitive anxiety model in an EFL country like Bangladesh.

In Bangladesh, English, a targeted second language, is taught from class one to undergraduate programs in all types of curricula in all types of institutions. At the tertiary level, English is used as the language of instruction in almost all universities and colleges. Unfortunately, the performance of the learners is no way near the expected level (Mamun, 2016; Sultana, 2018; Das, 2020; Rashid et al., 2018). They have shown that learners at different levels of study have a poor competence level, and moreover, their performance has been appalling. In Bangladesh, despite measures taken to increase the quality of English language teaching (ELT), the results are dissatisfactory (Ali \& Walker, 2014; Hamid \& Baldauf, 2008 as in Rahman et al., 2019). Besides the policy-related issues, the characteristics of the learners and their negative attitude, lack of motivation, and behavior in the English language classroom can be attributed to this ineffective acquisition of EFL and poor performance (Mamun et al., 2018; Das, 2020). Das (2020) has found that the tertiary level students' anxiety level was high, and it decreased the rate of their classroom participation. Rashid et al. (2020) have found nine anxiety-related factors like low self-esteem, fear of negative evaluation, peer pressure, etc. Thus, it is quite obvious that the tertiary level learners in Bangladesh suffer from anxiety which is characterized by unique contextual variables. In this perspective, this study wanted to

1) reveal the present level of anxiety of the tertiary level learners of Bangladesh

2) unveil the major sources of anxiety of the tertiary level learners in Bangladesh

\section{Literature Review}

Anxiety is "a distinctive complex of self-perceptions, beliefs, feelings, and behaviors related to classroom language learning arising from the uniqueness of the language learning process" (Horwitz, Horwitz \& Cope, 1986). The history of anxiety-related research dates back to the 1970s. In 1975, Chastain found a positive, a negative, and a non-significant correlation between anxiety and SLA. Kleinmann (1977) found both facilitating and debilitating anxieties. He suggested that the affective factors can have some role in FLA. Krashen (1981) came with his 'affective factor' hypothesis to mean that the affective factors, including anxiety, create blocks in the way of the inputs being transformed into intakes. Dulay \& Burt (1977) called the process 'socio-affective filter.'

Baily (1983) found that anxiety emerged from negative self-comparison and the level of anxiety changes with proficiency development. It has relation with tests, peer relationships, and teachers' attitudes. Anxiety can be context-specific and general (Gardner, 1985; Horwitz et al., 1986; MacIntyre and Gardner, 1995). Horwitz et al.'s (1986) anxiety model has three situation-specific constructs-communication apprehension (CA), fear of negative evaluation (FNE), and test anxiety (TA). They contend that "communication apprehension is a type of shyness characterized by fear of or anxiety about communicating with people; test anxiety refers to a type of performance anxiety stemming from a fear of failure"; and "fear of negative evaluation is the 'apprehension about others' evaluations, avoidance of evaluative situations and the expectation that others would evaluate oneself negatively." They developed a 'Foreign Language Classroom Anxiety Scale', which has been used in numerous studies throughout the world. Their findings show that anxious students have a fear of not understanding all the language input, and they are afraid to make mistakes. They conclude that some aspects of foreign language anxiety are experienced significantly by many students and "speaking is the most anxiety-provoking skill, and it is the greatest source of anxiety in language classrooms".

MacIntyre \& Gardner (1989) developed a model using Spielberger's (1983) State-Trait Anxiety Inventory and stated that the foreign language anxiety scale should be used for investigating FLA rather than any general anxiety scale. State-Trait Inventory attempts to define personality traits across different situations. "This study has shown that a clear relationship exists between foreign-language anxiety and foreign language proficiency" and "Clearly, anxiety was shown to influence both the learning (input) and production (output) of French vocabulary." Their findings substantiate the findings of Howritz et al. (1986) except regarding test anxiety. To promote a clear understanding of the FLA, more model developments are suggested by them.

Foss \& Reitzel (1988) developed a relational model to manage second language anxiety and listed a number of factors. The first factor of motivation can handle communication activities greatly, while the second factor, 'knowledge' postulates that learners get anxiety as second language activities may appear overwhelming. Thirdly, the learners need certain 'skills' to communicate successfully. To mitigate the anxiety, they design some 
activities and strategies: rational emotive therapy to boost motivation, an anxiety graph to make the learners understand the anxiety level, and to approach the communication situations more realistically. They maintain that "three activities commonly used in communication classrooms to help students gain knowledge of and skills in the language and culture are role-playing, drama, and oral interpretation." To help the students out with the contextual difficulties, they suggest using case studies and cultural artefact exercises.

Zheng (2008) classified anxiety from three different viewpoints- cognitive, cultural, and curriculum-policy related. The cognitive dimension asserts that the learners are anxious about being anxious, which diverts their attention, and the learning process gets affected. The environment in which they learn and the techniques of error correction of the teachers, the background experience, and diverse cultural understanding can also make them anxious.

Using the FLCAS of Howritz et al., Alrabai (2014) developed a model for the Saudi context. Communication anxiety, comprehension apprehension, and negative attitudes toward English class were the main sources of anxiety of the Saudi ELF learners. The most effective variables were categorized into two components: language use anxiety and language class anxiety.

Djafri and Wimbarti (2018) found that "learners' motivation does not affect foreign language anxiety. Meanwhile, their perception of teacher's behaviors significantly affects foreign language anxiety". They suggested that "foreign language teachers should give more attention to their teaching method and behaviors applied inside the classroom, and on how to create a more conducive learning environment in the classroom to reduce foreign language anxiety experienced by their students."

There has not been much research on language anxiety in the Bangladesh context. Das (2020) studied the relationship between anxiety and classroom participation, and she finds the anxiety suffered by both the urban and the rural learners has a negative impact on classroom participation. She suggested that "to reduce learners' anxiety and thus increase their active participation in the classroom, a flexible, humanistic and convivial learning environment should be ensured."

Rashid et al. (2020), in their study on students' anxiety features in speaking of Bangladesh, found nine factors responsible for increasing participants' fear which were divided into three components: self-esteem, classroom atmosphere, and peer pressure.

It is now clear that anxiety has drawn the attention of the experts, researchers, linguists, and practicing pedagogues, and different aspects of teaching-learning environment and learner's factors are related to anxiety which is highly "state, situation-specific," and has "trait characteristics" (MacIntyre, 2007). Thus, to ameliorate the learning of EFL situation, the prevalent triggers of anxiety are to be identified and addressed.

\subsection{Research Questions}

a) What is the present level of anxiety of the tertiary level learners in Bangladesh?

b) What are the major sources of anxiety of the tertiary level learners in Bangladesh?

\section{Research Method}

\subsection{Participants}

Students of both public and private universities from different areas of Bangladesh volunteered in the data collection process. All of them were Bangladeshi nationals with Bangla as their first language. Demographic and other information regarding them is presented in Table 1.

Table 1. Socio-demographic information of the participants ( $\mathrm{N}=337)$

\begin{tabular}{llll}
\hline Demographic Variable & Frequency & Percentage \\
\hline \multirow{2}{*}{ Gender } & Male & 181 & 53.7 \\
& Female & 156 & 46.3 \\
Age (18-22) & & 337 & 100 \\
\multirow{2}{*}{ University type } & Public & 166 & 49.3 \\
& Private & 171 & 50.7 \\
\hline
\end{tabular}




\subsection{Instruments}

To investigate foreign language anxiety (FLA), the FLCAS developed by Horwitz et al. (1986) was used. Researchers used this scale to understand the level and causes of anxiety across the world (Horwitz et al., 1986; Huang, 2008; Young \& Das, 2020, 1991; Zhao, 2007; Alrabai, 2014) because of its validity and reliability. On this FLCAS there are 33 items using 5-point Likert scale (1 (strongly disagree) to 5 (strongly agree). The sum of the scores ranges from 33 to 165; the higher the score higher the anxiety. Horwitz et al. (1986) maintained that the 33 items are to identify the three main sources of FLA: communication apprehension (items 1, 4, 9, 14, 15, $18,24,27,29,30$ and 32), test anxiety (items 3, 5, 6, 8, 10,11, 12, 16, 17, 20,21, 22, 25, 26 and 28), and fear of negative evaluation (items $2,7,13,19,23,31$ and 33). They also confirmed the reliability of the scale (alpha coefficient .93 and .83). This reliability has been reported in other studies too (Zhang, 2010; Das, 2020).

\subsection{Procedure}

Data were collected from November 2020 to January 2021, both personally and online. The respondents were informed of the procedure and the purpose of the data collection. At the beginning of the questionnaire, the respondents were asked to give their consent to take part in the study. Only the participants who gave their consent were requested and allowed to fill in the survey. They were guaranteed that their responses would remain confidential. For easy understanding and clarity of questions, Bangla translation was used along with English.

To reveal the levels of FLA, descriptive statistics were generated to find out the items with the highest mean scores which would indicate the major causes of FLA. To identify the components and subcomponents of the sources classroom FLA, an exploratory factor analysis (EFA) with principal component analysis and varimax rotation (Kaiser Normalization) was used.

\section{Results}

\subsection{Level of Anxiety}

Table 2 shows the level of anxiety of the tertiary level students. The anxiety scale is divided into five levels from 'Very low' to 'High' following Krinis's (2007 as in Alrabai, 2014) instance of the 20th, 40th, 60th, and 80th percentiles. A minor percentage of the students suffer from 'very low' anxiety which increases along the level. Around half of the students (46.3\%) suffer from a high level of anxiety while another $28.8 \%$ suffer from moderately high anxiety.

Table 2. Learners' anxiety level

\begin{tabular}{lllll}
\hline Level & Scores & Level of anxiety & Frequency & Percentage \\
\hline 1 & $33-82$ & Very low anxiety & 26 & 7.7 \\
2 & $83-89$ & Moderately low anxiety & 19 & 5.6 \\
3 & $90-98$ & Moderate & 39 & 11.6 \\
4 & $99-108$ & Moderately high anxiety & 97 & 28.8 \\
5 & $109-165$ & High anxiety & 156 & 46.3 \\
& & Total & 337 & 100
\end{tabular}

To understand the causes behind this high anxiety level of most of the students, an item analysis was conducted. Table 3 presents the items with their mean score in descending order. Six items (33, 9, 15, 23, 20 and 27) received the highest mean scores. Table 3 shows that item number 33, 'I get nervous when the language teacher asks questions that I haven't prepared for in advance' has got the highest mean which provides evidence of their anxiety over negative evaluation, followed by item number 9, 'I start to panic when I have to speak without preparation in English language class.' which proves serious nervousness experienced by the students in case of communication. Items 15 (I get upset when I don't understand what the teacher is correcting), 23 (I always feel that the other students speak English better than I do), and 20 (I can feel my heart pounding when I'm going to be called on in English language class) strengthen the proof of their being afraid negative evaluation. The next most important cause identified by them is embedded with item number 27 (I get nervous and confused when I am speaking in my English class), which substantiates their communication anxiety. Therefore, the students are anxious mainly because of their lack of preparation and lack of confidence in terms of communication performance. 
Table 3. Descriptive statistics of foreign language classroom anxiety scale

\begin{tabular}{|c|c|c|c|}
\hline Item & & Mean & $\mathrm{Sd}$ \\
\hline 33 & $\begin{array}{l}\text { I get nervous when the language teacher asks questions that I haven't prepared for } \\
\text { in advance. }\end{array}$ & 3.81 & .970 \\
\hline 9 & I start to panic when I have to speak without preparation in English language class. & 3.80 & 1.106 \\
\hline 15 & I get upset when I don't understand what the teacher is correcting. & 3.69 & 1.053 \\
\hline 23 & I always feel that the other students speak English better than I do. & 3.66 & 1.142 \\
\hline 20 & $\begin{array}{l}\text { I can feel my heart pounding when I'm going to be called on in English language } \\
\text { class. }\end{array}$ & 3.60 & 1.184 \\
\hline 27 & I get nervous and confused when I am speaking in my English class. & 3.60 & 1.106 \\
\hline 7 & I keep thinking that the other students are better at language than I am. & 3.57 & 1.194 \\
\hline 22 & I DON'T feel pressure to prepare very well for language class. & 3.57 & 1.070 \\
\hline 10 & I worry about the consequences of failing my language class. & 3.54 & 1.077 \\
\hline 30 & $\begin{array}{l}\text { I feel overwhelmed by the number of rules I have to learn to speak the English } \\
\text { language. }\end{array}$ & 3.53 & 1.066 \\
\hline 32 & I would probably feel comfortable around native speakers of English. & 3.52 & .985 \\
\hline 8 & I am usually at ease during tests in my language class. & 3.50 & 1.137 \\
\hline 11 & I don't understand why some people get so upset over language classes. & 3.50 & 1.030 \\
\hline 13 & It embarrasses me to volunteer answers in my language class. & 3.48 & 1.198 \\
\hline 29 & I get nervous when I don't understand every word the language teacher says. & 3.47 & 1.121 \\
\hline 5 & It wouldn't bother me at all to take more English language classes. & 3.47 & 1.121 \\
\hline 12 & In English language class, I can get so nervous that I forget things I know. & 3.40 & 1.209 \\
\hline 1 & I never feel quite sure of myself when I am speaking in English. & 3.35 & 1.125 \\
\hline 3 & I tremble when I know that I'm going to be called on in language class. & 3.31 & 1.203 \\
\hline 26 & I feel more tense and nervous in my language class than in my other classes. & 3.31 & 1.201 \\
\hline 16 & Even if I am well prepared for language class, I feel anxious about it. & 3.27 & 1.233 \\
\hline 4 & It frightens me when I don't understand what the teacher is saying in English. & 3.24 & 1.227 \\
\hline 2 & I DON'T worry about making mistakes in English class. & 3.20 & 1.126 \\
\hline 28 & When I'm on my way to language class, I feel very confident and relaxed. & 3.20 & 1.154 \\
\hline 31 & $\begin{array}{l}\text { I am afraid that the other students in the class will laugh at me when I speak in } \\
\text { English. }\end{array}$ & 3.19 & 1.311 \\
\hline 14 & I would NOT be nervous speaking English with native speakers. & 3.19 & 1.180 \\
\hline 19 & I am afraid that my language teacher is ready to correct every mistake I make. & 3.15 & 1.146 \\
\hline 25 & Language class moves so quickly that I worry about being left behind. & 3.12 & 1.228 \\
\hline 18 & I feel confident when I speak in English in my language class. & 3.08 & 1.155 \\
\hline 6 & $\begin{array}{l}\text { During language class, I find myself thinking about things that have nothing to do } \\
\text { with the course. }\end{array}$ & 3.04 & 1.225 \\
\hline 24 & I feel very self-confident about speaking English in front of the other students. & 3.01 & 1.173 \\
\hline 21 & The more I study for a language test, the more confused I get. & 2.88 & 1.226 \\
\hline 17 & I often feel like not going to my language class. & 2.60 & 1.287 \\
\hline
\end{tabular}

4.2 Sources of Anxiety

The factor analysis came up with a four-factor solution which accounts for $62.05 \%$ of the total variance making it a good solution (Tabachnick and Fidell, 2007). All the 33 items were loaded with the lowest value, .443. Thirteen items $(12,27,3,20,13,16,9,33,7,23,30,10$ and 26) were indexed as the first FLCAS component. This component includes learners' apprehension about communicating in the class and they are afraid and nervous of being inferior in terms of competence to other learners. They suffer from different psycho-physical symptoms due to their anxiety over these issues. Thus, the component can be termed as 'communication anxiety'.

The second component received loadings from 10 items $(24,18,28,2,14,22,32,8,11$ and 5) which were all positively worded and indicate the learners' 'lack of anxiety' and the component was labelled the same. 
The third component drew loadings from 7 items $(31,25,21,17,6,1$ and 19). These items mainly have the issues like how they feel in the classroom, and they are afraid of not being able to comprehend others both in classes and in tests and being comprehended by the teachers and the peers. They suffer from speaking anxiety and anxiety over making mistakes and are fearful of every mistake to be corrected by the teacher. So, this component was termed 'comprehension and test anxiety'.

Finally, the fourth component with loadings from three items (4, 15 and 29) demonstrated the learners' 'fear of negative evaluation'.

Table 4. Component matrix (varimax rotation) of the factors

\begin{tabular}{lc}
\hline & Factor \\
\cline { 2 - 2 } Statement & F1 \\
\hline 12. In English language class, I can get so nervous that I forget things I know. & .793 \\
27. I get nervous and confused when I am speaking in my English class. & .792 \\
3. I tremble when I know that I'm going to be called on in language class. & .763 \\
20. I can feel my heart pounding when I'm going to be called on in English language class. & .752 \\
13. It embarrasses me to volunteer answers in my language class. & .749 \\
16. Even if I am well prepared for language class, I feel anxious about it. & .745 \\
9. I start to panic when I have to speak without preparation in English language class. & .743 \\
33. I get nervous when the language teacher asks questions that I haven't prepared for in advance. & .733 \\
7. I keep thinking that the other students are better at language than I am. & .729 \\
23. I always feel that the other students speak English better than I do. & .729 \\
30. I feel overwhelmed by the number of rules I have to learn to speak the English language. & .718 \\
10. I worry about the consequences of failing my language class. & .716 \\
26. I feel more tense and nervous in my language class than in my other classes.
\end{tabular}

29. I get nervous when I don't understand every word the language teacher says.

15. I get upset when I don't understand what the teacher is correcting.

31. I am afraid that the other students in the class will laugh at me when I speak in English.

4. It frightens me when I don't understand what the teacher is saying in English.

25. Language class moves so quickly that I worry about being left behind.

21. The more I study for a language test, the more confused I get.

17. I often feel like not going to my language class.

24. I feel very self-confident about speaking English in front of the other students. $\quad .838$

18. I feel confident when I speak in English in my language class.

28. When I'm on my way to language class, I feel very confident and relaxed. $\quad .767$

2. I DON'T worry about making mistakes in English class. $\quad .715$

14. I would NOT be nervous speaking English with native speakers. $\quad .710$

22. I DON'T feel pressure to prepare very well for language class. $\quad .708$

32. I would probably feel comfortable around native speakers of English. $\quad .666$

8. I am usually at ease during tests in my language class.

11. I don't understand why some people get so upset over language classes.

5. It wouldn't bother me at all to take more English language classes.

6. During language class, I find myself thinking about things that have nothing to do with the $\quad .546$

1. I never feel quite sure of myself when I am speaking in English.

19. I am afraid that my language teacher is ready to correct every mistake I make.

Extraction Method: Principal Component Analysis. Rotation Method: Varimax with Kaiser Normalization (15 iterations). $\mathrm{F}=$ Factor. 
The first factor, communication anxiety, accounted for $32 \%$, the second factor 'lack of anxiety' $16 \%$, the third factor, comprehension and test anxiety, $10 \%$, and the fourth factor, fear of negative evaluation, $4 \%$ of the total variance. A number of items loaded for the second factor also had considerable loading for the third and the fourth factors which prove that the learners are afraid of those issues as well. From the analysis, it was found that the sources of anxiety of Bangladeshi EFL learners are diverse and variegated.

\section{Discussion}

The situation seems to be an alarming one regarding the level of anxiety. 253 students out of 330 from different areas of the country suffer from at least moderately high anxiety, of whom 156 from high anxiety. The descriptive statistics show that it is a ubiquitous scenario of the tertiary level of Bangladesh (SD range .97 to 1.31). This anxiety results from 23 different issues, personal, classroom-related, and social. Personal issues include lack of motivation and self-esteem, misconceptions regarding expectation, cognitive inability, preparation oriented, etc. Issues regarding classroom procedure and teaching-learning environment comprise teacher-learner and peer relationship, testing and error correction process, teaching methodology, etc. All of these issues are found to affect the speaking anxiety of Bangladeshi learners (Mobarak, 2020). The item analysis shows that the learners highly depend on their preparation for the specific lessons. In the absence of preparation, they get nervous and start to panic. It may be the result of a kind of 'pidginization' of their communicative ability in English, as it was found that learners with low proficiency levels have higher anxiety level (Young, 1991).

Social anxiety follows this communication apprehension. Low motivation and negative attitude to English language create low self- esteem (Mamun et al., 2018), which in addition to their negative comparison with the other learners, accelerate anxiety. Thus, they do not want to take part in classroom communication or volunteer to answer teachers' queries. In Bangladeshi context, cooperative or collaborative activities not frequently used in the classroom, which creates a bar in developing speaking or communication capacity for the learners. Also, outside the classroom, the learners rarely have any English language use situation. These contextual elements pave the way for them to suffer highly from speaking anxiety.

Teaching-learning procedure and over-emphasis on examination along testing procedure play another major role in shaping language anxiety. The characteristics and behavior of the teachers and the methodologies used by them in the classroom can be considered key elements for promoting the anxiety of the learners. At the tertiary level, almost no teacher is given any pedagogical training (Mamun, 2016). Lack of teachers' support, over-correction, negative evaluation of the performance of the learners, lack of personal attention due to large class size, the class being too much teacher-centered, emphasis on examination related aspects of learning, etc. have huge impact boosting anxiety. In this context, still, the grammar-translation method is used frequently emphasizing grammatical accuracy and written form rather than spoken (Amin, 2016). The teachers also do not give necessary feedback due to time constraints and large class size with heterogeneous capacity. The learners blame themselves for their errors and remain ashamed of them, which contribute to the lack of confidence and anxiety. Besides, the tests are conducted on written performance only. The final examination has a negligible part devoted to spoken performance and summative evaluation is mostly used. Thus, the learners without a clear idea of their capacity face the tests and they remain very anxious about their performance in those tests.

The previous studies on anxiety in the context of Bangladesh corroborate the finding of this study. Rashid et al. (2020) found low self-esteem of the students, non-supportive classroom environment, and peer pressure to be triggering factors for anxiety. Sultana (2018) found teachers' reactions to being another factor. The findings of these study along with the previous ones support the existence of such factors creating and contributing to learners' anxiety of English language.

A close analysis of the EFA, Gardner's (1985) social-psychological model, Horwitz et al.'s (1986) classification of the components of anxiety, and Alrabai's (2014) model of anxiety of the Saudi students, the anxiety variables were divided into six factors: speaking anxiety, fear of negative evaluation, peer pressure/social-image, comprehension-related anxiety, negative attitude towards class, and test anxiety.

Table 5 shows the correlation between the components that emerged from the EFA. The first component, 'speaking anxiety', significantly $(\mathrm{r}=.390)$ correlated with the fear of being negatively evaluated by the teachers and their peers and with their comprehension apprehension $(\mathrm{r}=.482)$. Due to this high speaking anxiety, they developed a negative attitude towards language classes $(\mathrm{r}=.566)$. It is to be noted that speaking anxiety has no significant direct relation with peer pressure or social anxiety and test anxiety, but it certainly affects them indirectly because fear of negative evaluation is highly correlated with social anxiety and it in addition to comprehension anxiety affect their test anxiety. 
The second component, 'fear of negative evaluation', is highly correlated with all other components and it constitutes the most affective anxiety. Of them, it has got the highest correlation with the fourth factor 'comprehension apprehension' ( $\mathrm{r}=.659)$. This component is responsible for making the students' nervous' 'embarrassed' and, 'confused' which stand in the way of using their already-gained knowledge of the language. They remain afraid of being asked to answer or volunteering an answer. Besides, it affects their interpersonal relationship with their peers. The third-factor 'peer pressure or social anxiety' significantly correlated with test anxiety $(\mathrm{r}=.289)$ besides the second component $(\mathrm{r}=.212)$. Its relationship with the second component makes it a contributor to other types of anxiety indirectly.

The fourth component, 'comprehension apprehension', correlated with all other components except 'peer pressure'. Of them, it has got highly significant relation with 'fear of negative evaluation $(\mathrm{r}=.659)$ followed by its correlation with speaking anxiety, negative attitude towards language class, and test anxiety. It is one of the components triggering fear related to tests $(r=437)$. The anxiety emerging out of comprehension apprehension negatively affects proper communication (Atasheneh and Izadi, 2012 as in Alrabai, 2014) through speaking and listening. Listening is the most neglected skill, followed by speaking in the context of Bangladesh. Here, the learners get a very scanty opportunity to be exposed to real-life English language use. The environment of the classroom, the only place for using English for communication, is not congenial for developing communicative competence due to teaching method and instructional materials, teacher dominated lecture-based lessons, lack of activities, too much emphasis on examination, only written tests, use of mostly printed materials, less use of technology, etc. (Rahman, Pandian, \& Kaur, 2018; Karim \& Mohamed, 2019; Rahman, Islam, \& Karim, 2019).

The next factor, 'negative attitude towards English class', correlated with speaking anxiety, fear of negative evaluation, and comprehension apprehension. In Bangladesh, the tertiary level learners' negative attitude is a major cause of their lack of proficiency in English (Mamun et al., 2018). This negative attitude, along with other anxiety factors makes the classroom a discomfort zone, and they feel like not belonging there. They grow an introverted perspective and lack motivation in being involved in communication with others. Since English is studied as an academic subject in the study context, they do not feel the urge to improve their competence beyond the level required for passing the examination.

The last factor, 'test anxiety', correlated with fear of negative evaluation, social anxiety and comprehension apprehension. Test anxiety is a negative predictor of language achievement (Zheng, Y. \& Cheng, L., 2018) and affects other traits of the learning process (Aida, 1994).

Table 5. Correlation between Components

\begin{tabular}{|c|c|c|c|c|c|c|}
\hline Components & $\begin{array}{l}\text { Speaking } \\
\text { Anxiety }\end{array}$ & $\begin{array}{l}\text { Fear of Negative } \\
\text { Evaluation }\end{array}$ & $\begin{array}{l}\text { Peer Pressure/ } \\
\text { Social Anxiety }\end{array}$ & $\begin{array}{l}\text { Comprehension } \\
\text { Apprehension }\end{array}$ & $\begin{array}{l}\text { Negative Attitude } \\
\text { towards Class }\end{array}$ & $\begin{array}{l}\text { Test } \\
\text { Anxiety }\end{array}$ \\
\hline Speaking Anxiety & 1 & $.390^{* *}$ & .018 & $.482^{* *}$ & $.566^{* *}$ & .105 \\
\hline $\begin{array}{l}\text { Fear of Negative } \\
\text { Evaluation }\end{array}$ & $.390^{* *}$ & 1 & $.212^{* *}$ & $.659^{* *}$ & $.258^{* *}$ & $.475^{* *}$ \\
\hline $\begin{array}{l}\text { Peer Pressure/Social } \\
\text { Anxiety }\end{array}$ & .018 & $.212^{* *}$ & 1 & .064 & .004 & $.289^{* *}$ \\
\hline $\begin{array}{l}\text { Comprehension } \\
\text { Apprehension }\end{array}$ & $.482^{* *}$ & $.659^{* *}$ & .064 & 1 & $.366^{* *}$ & $.437^{* *}$ \\
\hline $\begin{array}{l}\text { Negative Attitude } \\
\text { towards Class }\end{array}$ & $.566^{* *}$ & $.258^{* *}$ & .004 & $.366^{* *}$ & 1 & .024 \\
\hline Test Anxiety & .105 & $.475^{* *}$ & $.289^{* *}$ & $.437^{* *}$ & .024 & 1 \\
\hline
\end{tabular}

${ }^{* *}$ Correlations are significant at the .01 level.

\section{Conclusion}

The study has measured the level of anxiety of the tertiary level students of Bangladesh, unveiled the sources of their anxiety. The respondents of this study were found to have a high English language anxiety primarily caused by communication anxiety, comprehension apprehension, fear of negative evaluation, and negative attitude towards class. These variegated sources make anxiety a multi-dimensional and complex issue.

These findings can undoubtedly contribute to creating awareness of the teachers, the learners, administrators, and the policymakers of the causes of anxiety, and they should acknowledge the existence of high anxiety and take effective measures to curb the anxiety to ameliorate English language performance. There should be 
opportunities for the teachers to get pedagogical training as they can play the most important role in helping the students overcome anxiety. They should apply fitting methodology, improve interactions with the students, develop interesting materials, and try to build the confidence and self-esteem of the students through motivation, positive reinforcement, timely feedback, and empathy to alleviate the anxiety. There should be ample opportunities for the students to practice speaking and listening skills. Besides using formative assessment, in the final examination, these two skills should be included. Measures should be taken to understand the underlying individualized causes of anxiety. In addition to them, a congenial and supportive teaching-learning environment, a friendly, helpful, and cooperative behavior (Alrabai, 2014) can help the students remain positive and lessen anxiety.

This study has presented sufficient statistical data which can support a model of anxiety with immense potential for improving the English teaching-learning situation in Bangladesh.

\section{Funding}

This study was funded by Jashore University of Science and Technology.

\section{References}

Aida, Y. (1994). Examination of Horwitz, Horwitz, and Cope's construct of foreign language anxiety: The case of students of Japanese. Modern Language Journal, 78, 155-167. https://doi.org/10.1111/j.1540-4781.1994.tb02026.x

Alrabai, F. (2014). A Model of Foreign Language Anxiety in the Saudi EFL Context. English language teaching, 7(7), 82-101. https://doi.org/10.5539/elt.v7n7p82

Amin, R. (2016). ELT: An Overall Insight into the Paradigm Shift in the Teaching-Learning Condition in Bangladesh. Crossings, (7), 144-151.

Aydin, S. (2009). Test anxiety among foreign language learners: A review of literature. Dil ve Dilbilimi Çalışmaları Dergisi, 5(1).

Bailey, K. M. (1983). Competitiveness and anxiety in adult second language learning: Looking at and through the diary studies. In H. W. Seliger \& M. H. Long (Eds.), Classroom oriented research in second language acquisition (pp. 67-102). Rowley, MA: Newbury House.

Chastain, K. (1975). Affective and ability factors in second language acquisition. Language Learning, 25, 153-161. https://doi.org/10.1111/j.1467-1770.1975.tb00115.x

Das, C. R. (2020). Students' Perceptions of their English Language Anxiety and its Role on their Classroom Participation: An Exploration of EFL Anxiety in Urban and Peripheral Contexts of Bangladesh. International Journal of English Literature and Social Sciences (IJELS), 5(1). https://doi.org/10.22161/ijels.51.47

Demirdaş, Ö., \& Bozdoğan, D. (2013). Foreign language anxiety and performance of language learners in preparatory classes. Turkish Journal of Education, 2(3). https://doi.org/10.19128/turje.181060

Djafri, F., \& Wimbarti, S. (2018). Measuring foreign language anxiety among learners of different foreign languages: In relation to motivation and perception of teacher's behaviors. Asian-Pacific Journal of Second and Foreign Language Education, 3(1), 17. https://doi.org/10.1186/s40862-018-0058-y

Dörnyei, Z. (2009). Individual differences: Interplay of learner characteristics and learning environment. Language Learning, 59(Suppl. 1), 230-248. https://doi.org/10.1111/j.1467-9922.2009.00542.x

Dulay, H., \& Burt, M. (1977). Remarks on creativity in language acquisition. In M. Burt, H. Dulay \& M. Finnochiaro (Eds.), Viewpoints on English as a second language (pp. 95-126). New York: Regents.

Elkhafaifi, H. (2005). Listening comprehension and anxiety in the Arabic language classroom. The Modern Language Journal, 89, 206-220. https://doi.org/10.1111/j.1540-4781.2005.00275.x

Foss, K. A., \& Reitzel, A. C. (1988). A relational model for managing second language anxiety. TESOL quarterly, 22(3), 437-454. https://doi.org/10.2307/3587288

Horwitz, E. (2010). Foreign and second language anxiety. Language Teaching, 43(2), 154-167. https://doi.org/10.1017/S026144480999036X

Horwitz, E. K. (1986). Preliminary evidence for the reliability and validity of a foreign language anxiety scale. TESOL Quarterly, 20, 559-562. https://doi.org/10.2307/3586302 
Horwitz, E. K., Horwitz, M. B., \& Cope, J. A. (1986). Foreign language classroom anxiety. Modern Language Journal, 70, 125-132. https://doi.org/10.1111/j.1540-4781.1986.tb05256.x

Karim, A., \& Mohamed, A. R. (2019). Examining the impact of an English in action training program on secondary-school English teachers' classroom practice in Bangladesh examining the impact of an English in action training program on. Qualitative Report, 24(3), 441-469. https://doi.org/10.46743/2160-3715/2019.3703

Kleinmann, H. H. (1977). Avoidance behavior in adult second language acquisition. Language Learning, 27(1), 93-107. https://doi.org/10.1111/j.1467-1770.1977.tb00294.x

Krashen, S. D. (1981). Second language acquisition and second language learning. New York: Pergamon.

Krinis, A. (2007). Foreign language anxiety: A presentation to Greek language teachers. Retrieved from https://hellenic-education-uk.europe.sch.gr/

MacIntyre, P. D. (2007). Willingness to communicate in the second language: Understanding the decision to speak as a volitional process. The Modern Language Journal, 91(4), 564-576. https://doi.org/10.1111/j.1540-4781.2007.00623.x

MacIntyre, P. D., \& Gardner, R. C. (1989). Anxiety and second-language learning: Toward a theoretical clarification. Language learning, 39(2), 251-275. https://doi.org/10.1111/j.1467-1770.1989.tb00423.x

MacIntyre, P. D., \& Gardner, R. C. (1991). Methods and results in the study of anxiety and language learning: A review of the literature. Language Learning, 41, 85-117. https://doi.org/10.1111/j.1467-1770.1991.tb00677.x

Mamun, M. A. A. (2016). Designing a Needs-based Syllabus for University Level Learners of Bangladesh. Unpublished PhD Dissertation. Institute of Bangladesh Studies, Rajshahi University.

Mamun, M. A. A., Rahman, M. M., \& Chowdhury, F. (2018). Attitude and Motivation for Learning English and their Impact on Performance: A Study on Engineering Students of Jessore University of Science and Technology. International Journal of English Literature and Social Sciences, 3(5). https://doi.org/10.22161/ijels.3.5.29

Mobarak, M. S. K. (2020). Reasons for English Language Speaking Anxiety among Students in Private Universities of Bangladesh. Journal of Education and Social Sciences, 1(16).

Öztürk, G., \& Gürbüz, N. (2013). The impact of gender on foreign language speaking anxiety and motivation. Procedia-Social and Behavioral Sciences, 70, 654-665. https://doi.org/10.1016/j.sbspro.2013.01.106

Philips, E. M. (1992). The effects of language anxiety on students' oral test performance and attitudes. The Modern Language Journal, 76, 14-26. https://doi.org/10.1111/j.1540-4781.1992.tb02573.x

Piniel, K., \& Csizér, K. (2013). L2 motivation, anxiety and self-efficacy: The interrelationship of individual variables in the secondary school context. Studies in second language learning and teaching, 3(4). https://doi.org/10.14746/ssllt.2013.3.4.5

Rahman, M. M., Islam, M. S., Karim, A., Chowdhury, T. A., Rahman, M. M., Seraj, P. M. I., \& Singh, M. K. M. (2019). English language teaching in Bangladesh today: Issues, outcomes and implications. Language Testing in Asia, 9(1), 9. https://doi.org/10.1186/s40468-019-0085-8

Rahman, M. M., Pandian, A., \& Kaur, M. (2018). Factors affecting teachers' implementation of communicative language teaching curriculum in secondary schools in Bangladesh. Qualitative Report, 5, 23. https://doi.org/10.46743/2160-3715/2018.3220

Rashid, M. H., Victor, S. S., Islam, J., \& Li, W. (2020). An Investigation of EFL Students' Anxiety Features in Speaking of Bangladesh. International Journal of Social Science and Education Research, 1(2), 59-65.

Salehi, M., \& Marefat, F. (2014). The Effects of Foreign Language Anxiety and Test Anxiety on Foreign Language Test Performance. Theory \& Practice in Language Studies, 4(5). https://doi.org/10.4304/tpls.4.5.931-940

Sertçetin, A. (2006). Classroom foreign language anxiety among Turkish primary school students (Unpublished master's thesis). Uludağ University, Bursa, Turkey.

Sultana, Z. (2018). The Role of Anxiety in Learning and Performing English in the Cadet College Classes: Bangladesh Perspective. Advances in Language and Literary Studies, 9(5), 111-120. https://doi.org/10.7575/aiac.alls.v.9n.5p.111 
Tabachnick, B. G., \& Fidell, L. S. (2007). Using multivariate statistics. Boston, MA: Pearson/Allyn and Bacon.

Young, D. J. (1991). Creating a low-anxiety classroom environment: What does the anxiety research suggest? Modern Language Journal, 75, 426-439. https://doi.org/10.1111/j.1540-4781.1991.tb05378.x

Zhang, H. (2010). An investigation of foreign language anxiety on EFL vocational high school students in China (Seminar paper). University of Wisconsin-Platteville, Platteville, WI.

Zheng, Y., \& Cheng, L. (2018). How does anxiety influence language performance? From the perspectives of foreign language classroom anxiety and cognitive test anxiety. Language Test in Asia, 8. https://doi.org/10.1186/s40468-018-0065-4

Zheng, Y. (2008). Anxiety and Second/Foreign Language Learning Revisited. Canadian Journal for New Scholars in Education, 1(1), 1-12. 


\section{Appendix A}

\section{Foreign Language Classroom Anxiety Scale (FLCAS developed by Horwitz et al., 1986)}

\begin{tabular}{|c|c|c|c|c|c|c|c|}
\hline 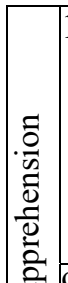 & 1 & I never feel quite sure of myself when I am speaking in English. & 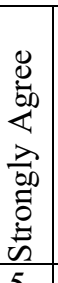 & 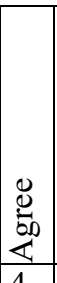 & 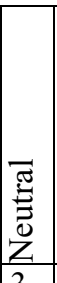 & 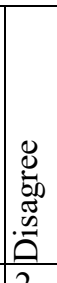 & 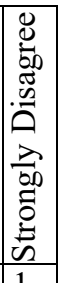 \\
\hline कि & & I start to panic when I have to speak without preparation in language class. & 5 & 4 & 3 & 2 & 1 \\
\hline .0. & 14 & I would NOT be nervous speaking English with native speakers. & & & & & \\
\hline . & 18 I & I feel confident when I speak in English in my language class. & & & & & \\
\hline ב्ב 2 & 24 II & I feel very self-conscious about speaking English in front of the other students. & & & & & \\
\hline ठี & 27 & I get nervous and confused when I am speaking in my language class. & & & & & \\
\hline & 29 II & I get nervous when I don't understand every word the language teacher says. & & & & & \\
\hline & 32 II & I would probably feel comfortable around native speakers of English. & & & & & \\
\hline & 3 & I tremble when I know that I'm going to be called on in language class. & & & & & \\
\hline$\approx$ & 7 & I keep thinking that the other students are better at language than I am. & & & & & \\
\hline 䜦 & 13 & It embarrasses me to volunteer answers in my language class. & & & & & \\
\hline$\stackrel{\pi}{\pi}$ & 15 | & I get upset when I don't understand what the teacher is correcting. & & & & & \\
\hline$\$ 2$ & 201 & I can feel my heart pounding when I'm going to be called on in language class. & & & & & \\
\hline$\overbrace{0,0}^{E}$ & 23 & I always feel that the other students speak English better than I do. & & & & & \\
\hline$\stackrel{\mathscr{Z}}{\mathscr{E}}$ & $25 \mathrm{I}$ & Language class moves so quickly that I worry about being left behind. & & & & & \\
\hline 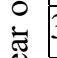 & $31 \mathrm{I}$ & I am afraid that the other students in the class will laugh at me when I speak in English. & & & & & \\
\hline & 33 11 & $\begin{array}{l}\text { I get nervous when the language teacher asks questions that I haven't prepared for in } \\
\text { advance. }\end{array}$ & & & & & \\
\hline & 2 & I DON'T worry about making mistakes in language class. & & & & & \\
\hline. & 8 & I am usually at ease (comfortable) during tests in my language class. & & & & & \\
\hline 彥 & 101 & I worry about the consequences of failing my language class. & & & & & \\
\hline 苞 & 19 & I am afraid that my language teacher is ready to correct every mistake I make. & & & & & \\
\hline & 21 & The more I study for a language test, the more confused I get. & & & & & \\
\hline & 4 & It frightens me when I don't understand what the teacher is saying in English. & & & & & \\
\hline & \begin{tabular}{|l|l|l|l}
5 & 1 & -1
\end{tabular} & It wouldn't bother me at all to take more English language classes. & & & & & \\
\hline$\ddot{\delta}$ & 6 & $\begin{array}{l}\text { During language class, I find myself thinking about things that have nothing to do with } \\
\text { the course. }\end{array}$ & & & & & \\
\hline$\frac{\frac{\pi}{0}}{0}$ & 11 I & I don't understand why some people get so upset over language classes & & & & & \\
\hline ज्ञ & 12 & In language class, I can get so nervous that I forget things I know. & & & & & \\
\hline की & 16 & Even if I am well prepared for language class, I feel anxious about it. & & & & & \\
\hline 4 & 17 & I often feel like not going to my language class. & & & & & \\
\hline $\overrightarrow{2}_{0}^{0}$ & 22 & I DON'T feel pressure to prepare very well for language class. & & & & & \\
\hline$\stackrel{\star}{a}$ & 26 & I feel more tense and nervous in my language class than in my other classes. & & & & & \\
\hline & 28 & When I'm on my way to language class, I feel very confident and relaxed. & & & & & \\
\hline & 30 & $\begin{array}{l}\text { I feel overwhelmed by the number of rules you have to learn to speak the Er } \\
\text { language. }\end{array}$ & & & & & \\
\hline
\end{tabular}

\section{Copyrights}

Copyright for this article is retained by the author(s), with first publication rights granted to the journal.

This is an open-access article distributed under the terms and conditions of the Creative Commons Attribution license (http://creativecommons.org/licenses/by/4.0/). 